\title{
Play and Body in the Children's Education. From the Frivolity to Intensity
}

\section{Rivero I* \\ Doctor of Education, Research professor at the National University of Río Cuarto, Argentina}

*Corresponding author: Ivana Rivero, Doctor of Education, Research professor at the National University of Río Cuarto, Postdoctoral Fellow of the National Council for Scientific and Technical Research (CONICET), Argentina, Tel: +54 9358 4243802; Email: irivero@hum. unrc.edu.ar

\section{Research article}

Volume 4 Issue 4

Received Date: September 20, 2021

Published Date: October 05, 2021

DOI: $10.23880 /$ phij-16000198

\section{Abstract}

This writing refers to the position taken at table of play of the International Symposium on Early Childhood Education: Pedagogical Challenges for the coming years, organized by the Ministry of Education and Sports of the Argentine Republic, together with the Organization of Ibero-American States for Education, Science and Culture (OEI) regarding the discussion about the obligatory of the three years classroom in Argentina.

The presentation puts collective play experiences in early childhood education at the center of the scene, experiences that, in times of virtuality, claim the bodily dimension and the construction of their availability to move and meet others.

Starting with the question, why play in early childhood education? I stop to analyze frivolity and order, two benefits that education has highlighted to include it in educational proposals. I will move forward untangling the bodily availability that promotes that decision, and presenting data that show the need to think about the game in education from and for child wellbeing. I conclude by emphasizing the other side of the aforementioned benefits, that is, intensity and innovation, to promote more inclusive, healthy and humane playful practices in early childhood education.

Keywords: Virtuality; Education; Argentina; Early Childhood

\section{Introduction}

Argentina assumed the postulates of the 1989 Convention on the Rights of Children as own, among which it recognizes "the right of the child to rest and recreation, to play and recreational activities appropriate to their age and to participate freely in cultural life and the arts" (Article 31). Thus, in Argentina, play is a children's right, extendable to legal subjects (not only children but also older adults ${ }^{1}$,

1 In mid-2015, the Organization of American States (OAS) approved the Inter-American Convention on the Protection of the Human Rights of Older Persons, an initiative promoted by Argentina whose objective is to "promote, protect and ensure the recognition and full enjoyment and exercise, under conditions of equality, of all human rights and fundamental freedoms of disabled people, women) and, therefore, the responsibility of adults $^{2}$.

As a university teacher, I assume the responsibility of producing knowledge about the game and training expert professionals in it, capable of making decisions that protect the right to play and education for recreation. I am a teacher in the Department of Physical Education of the National

the elderly, in order to contribute to their full inclusion, integration and participation in society "

2 Rivero, I. Playing with others: children's rights, teachers' responsibility. Journal of Physical Education La Pampa en Movimiento. No. 12. October 2012, p. 6-9 


\section{Philosophy International Journal}

University of Río Cuarto, Córdoba, Argentina, and our work team promotes and supports proposals for undergraduate and postgraduate teaching, extension and research projects on the game for Physical Education and for Initial Level.

Play is a highly inclusive practice incorporated into child and youth cultures, into their everyday ways of proceeding. The game cuts through culture, configures it. It not only expresses uses and customs of a culture, otherwise creates them. Already in 1948 Huizinga announced that the game is older than culture, that it responds to the impulse to produce culture, "it is a function full of meaning" [1]. If the game is at the base of the production of culture then it becomes an object of study for education.

Even when the thesis of Huizinga (the first philosopher to assign play an autonomous space in academic reflections) is affirmed in the depth of the roots of the game to man, to the point of understanding that it is not only a cultural product but that it produces culture, ambition productive performance of man has led him to blur the purpose of the practice of playing. The aesthetic intentionality of the game has been displaced by the productive intentionality.

Batiuk [2] points out that educational inequality for early childhood is resolved both by access and by the quality of services. It also states that there is an increase in accessibility to early childhood education that can be explained by the convergence of the legal provision to universalize the offer and the prioritization of inclusion policies, so we are concerned here with thinking about the quality of the game proposals for boys and girls, so that the promotion of more inclusive recreational practices will be a challenge for the coming years.

\section{Frivolity and Order: Of the Game as a Resource}

In front of the question, why play in early childhood education? the first search was in history, looking there for traces of the benefits of the game recognized by education to be included in its agenda.

With a history that recognized distraction and recreation as the only utility, an issue that inspired the dismissal suffered during the Middle Ages, the game entered the agenda of educational concerns only at the dawn of modernity. This incorporation is facilitated by the notion of childhood that begins to build up in discussions about the usefulness of man's activities.

Precisely, at the end of the 18th century, the search for effectiveness and efficiency in the activities carried out on a daily basis arouses the concern for optimizing the conditions for the production of knowledge. In this context and immersed in scientific pretensions for the study of people's behavior, Psychology escapes metaphysical explanations by approaching Biology, and finds in education a field of intervention where it can expand its domain [3].

Psychology facilitates the incorporation of the game in educational experiences and tests the first justifications for its value as a behavior characteristic of the species, that is, it finds a biological foundation. In principle, as training of inherited instincts (hence Groos's game theory), then as behavior of adaptability to the environment guaranteeing survival (recapitulation theory based on Darwinism), the game enters the educational agenda as a natural, pleasant activity that facilitates the adaptability of man to the surrounding physical and social environment.

This explains why studies on gambling have advanced in its presentation as a useful instrument for the development of people, which can be used to achieve a result extrinsic to the practice itself. Faced with the initial question, it could be said that the game enters the field of educational concerns because it is an efficient educational resource [4] for the promotion of knowledge considered valuable for the community. This position could be associated with the idea expressed by Plato of 'educating by playing' which seems to persist consistently in classrooms with the notion of 'educational game'.

The educational game is an expression that arises from studies based on Froebelian and Decrolyan texts interested in early childhood education ${ }^{3}$ and designates a particular way of relating play and education, making children's play a means to educate, a controlled educational support. The educational game refers to an occupation that has the appearance of a game, an occupation that satisfies the child's need to play while fulfilling an educational role [5].

Without the intention of summarizing the construction of the notion of educational game, it will be important to highlight that authors dedicated to the study of the incorporation of the game into education [5-7] coincide in supporting the Minus two ideas that are appropriate to understand why play in Early Childhood Education. The first one is that man brings with him the tendency to gamble. The second is that gambling is an activity that has no consequences in everyday life, that is, it is frivolous. Although the relationship between play and education is complex

3 According to Brougere (1998) the term 'educational game' is used for the first time in a 1911 text by Jeanne Girard, who was then an inspector of French nursery schools. However, in 1907 Decroly already conceived the educational game, as an intervention of educational activity in nature to straighten what deviates and to draw attention to what is not in the environment 


\section{Philosophy International Journal}

because it has been built on the opposition between play and seriousness, for the aforementioned authors it is possible to discover educational values in play that make it a serious activity, at least for children. It would be precisely its frivolity that makes the game a possible place of education, since the absence of consequences typical of playful activity would make it an environment of excellence for exploration.

Hence the justification for the use that the teacher makes of the game to improve his pedagogical intervention, proposing materials or situations that require actions aimed at the acquisition or training of specific content or skills, which is also known as an educational game in a restricted sense or 'didactic game' [8] worked by Chateau [9], Brougere [5], Kishimoto [7], among others. This posture recovers the classical Rome conception of the game, according to which the game is seen from the viewer and not from the participant [5]. The discovery of a value in the decisions of the participants involves someone who previously takes a distance, observes the events panoramic and interprets them in the light of a prefigured conceptual framework (an effort that would never be made by someone who surrenders to the future of the game).

Now, frivolity, the absence of consequences in everyday life, in the game is exhibited in all its power, for better and for worse. Thus, the game is not only an environment of exploration for the appropriation of the world, but also a safe place for inappropriate actions towards the other.

Precisely, to control the dispersion and avoid the distortion of educational intentionality, educational games gain meaning in the rules that announce what is allowed and what is prohibited. The rules of the game force players to think of increasingly elaborate strategies, moving from an innocent, fluctuating and unpredictable game, to a strategic game, scheduled and feasible to be anticipated. Respect for the established rules becomes essential, the challenge to face to make a difference with the adversary. Here Von Neuman's theory of the game with the prisoner's dilemma gains recognition.

Order and frivolity come qualities of the game that have presented it as an educational setting, highlighting in the players the attitudes of respect, for the normative framework that regulates social relations between the participants, daring because it requires an encouragement to try to overcome a challenge, and of forgiveness, to whom, by rehearsing possible responses, exerts an inappropriate action on the other (a blow, a mockery, collisions, shoves).

The educational proposals based on games that start from the recognition of order and frivolity, establish a particular aesthetic around a harmony built by the sum of individual explorations or movements that, articulated or placed side by side, trace relatively stable rhythms and circular that enable repetition and, with it, improve it.

The problem is that not all players have a basic competence to play: not all of them manage to detach themselves from reality easily, in other words, it is not always or all the time for the players. In some cases, this difficulty lies in the need to consciously master the skills required by the game (typical of the unskilled), in other cases it lies in a decision learned from the environment (typical of what is said to be competitive).

So for the game to be educational, that is, for the necessary frivolity to occur so that the players are encouraged to explore and rehearse (what attracted Piaget, Vygotsky, Bruner), it must first be inclusive, in other words, it must first guarantee everyone the opportunity to participate. And although this guarantee, which is the responsibility of the adults in charge of the proposals, can begin in the chosen form of the game, it requires a second basic competence to be able to play: the sensitivity to put oneself in the place of the other.

Although the official history of the incorporation of the Game into Education is traced by the hand of Pedagogical Psychology, Pedagogy did not exhaust its potential in relation to Psychology, but continued to receive reflections from the Social Sciences, from of which today it is possible to travel an alternative path to solve a problem of our times: the consideration of the other, the deal.

Many children arrive at first school lacking in home play experiences, opportunities to build knowledge that until not long ago was discounted as apprehended (incorporated into practice): enjoy playing with others; In terms of Pavía [10]: 'play in a playful way'.

Not all children find in their daily environments the opportunity to have someone who teaches them to experience this momentary and voluntary suspension of reflective consciousness to leave everything in the hands of what is to come, the novelty, with the certainty of knowing that nothing bad will happen.

The reduced availability and not always guaranteed by public policies of appropriate spaces and moments to play with others, and the media bombardment of virtual games, force to question the ethics that underlie approved, expected and even encouraged decisions in educational contexts

As an action of the people involved, playing carries decisions that, although personal, have a dense community load, unique and unrepeatable decisions that are learned to take to sustain the bias of uncertainty, ignorance and 
unpredictability in a framework of trust that characterizes the action such as playing (and not doing something else, such as working, competing, or fighting).

\section{The Body in the Game}

Cañeque [11] agrees that, by recognizing play as an appropriate, necessary and educational activity in children, their playful behavior is curtailed. This intention to redefine playfulness is crystallized in the expression: 'stop playing!', A phrase with which adults usually correct children's attitudes. In 2001, Mantilla stated that the game follows a unilinear path with no return. As the years go by, people lose our plasticity to surrender to the game, to trust the decisions of our fellow players. As the years go by, people make the game more complex, moving away from the inherent uncertainty and contingency in order to rationalize it [12].

That same direction seems to follow the use of the body in the game. The predominance of the knowledge generated in the field of Psychology has installed the belief that the motor component of a game decreases progressively as its complexity increases, becoming evident the Piagetian description of the evolutionary development of the person ${ }^{4}$ and, with it, the classic Cartesian body / mind distinction: the greater the bodily engagement, the less the intellectual engagement. It follows then that the most important games are intellectual; that the important and complex motor games are sports games because they involve actions thought within the framework of rigid rules that do not admit transgression, while popular games, recreational, artistic, aestheticexpressive activities would be relatively simple. The older the chronological age, either the body commitment of the chosen games decreases (more sedentary games are chosen), or the body commitment becomes polished and refined by training (complex game forms are chosen that bring it closer to sport or theater).

It is true, the presence of a gambling situation exceeds the limits of bodily engagement, as a person can be gambling without compromising his or her body. This is the case of solitaire, pinball, or virtual games. However, it must be said that more than games are personal challenges, because, although it is played on a network, each player has his goal, and strives to achieve it. They are entertainments. The person involved feels entertained, contained between the

4 Es atendible aquí la nota de color que, a fines de los noventa, Patricia Stokoe, como representante argentina en la producción colectiva de la Asociación Internacional por el Derecho del Niño a Jugar (IPA), El juego: necesidad, arte y derecho. La autora sugiere allí no desatender las condiciones de producción del conocimiento en vigencia en esos días en materia de juego. Puntualmente allí invita a desarticular la aplicación directa de las producciones de Piaget, impulsadas desde una realidad social francesa en sobra diferente a la actual y local. poles of emotional tension [1], oscillating between ecstasy and abandonment.

Something very different happens when children come face to face without toys and with time to lose, when presence gains ground, when faced with the demand to make decisions to enter into agreements, it is discovered that the body makes possible and at the same time evidences the Difficulty relating to others. A look, a gesture, a smile, is enough to understand an invitation to play.

In bodily terms, attending to children's right to play implies compensating for the idea of training spectators of the virtuous game of a few (who no longer play but work, and which is no longer a game but sport, spectacle or both) to teach putting the body to the game, to the popular game [13], to the motor game with others [14].

The Convention on the Rights of the Child not only said to play as a right of the little ones, but it formally presents it associated with rest and recreation to attend to their wellbeing, that is, the favorable balance state of the person in its complexity (in terms of physical, cognition, sensitivity, emotionality and sociability) that is recognized as healthy ${ }^{5}$.

In 2013, UNICEF published the General Observations of the Committee on the Rights of the Child, which expresses concern about the scant recognition that States grant to the rights contained in article 31 (absence of investment in adequate provisions, weak or non-existent protective legislation and the invisibility of children in planning at the national and local levels) and by the diminished opportunities that children find to enjoy the right to play. At this point, according to the Committee, child labor, domestic chores or the increasing demands of education reduce the time available for the enjoyment of these rights [15].

Argentina is not alien to this description. As shown by the results of an investigation with children under 5 years of age who attend kindergartens in the Municipality of Córdoba [16], the community and public policies play a decisive role in the construction of bodily availability, according to Gomez

5 Ya en 1946, la Organización Mundial de la Salud entendía que "la salud es un estado de completo bienestar físico, mental y social, y no solamente la ausencia de afecciones o enfermedades". Partiendo de esta definición, al hablar de salud entran en consideración, según Restrepo y Málaga (2001) dos aspectos fundamentales: la satisfacción de necesidades básicas (es decir, tener donde vivir, qué comer, donde acudir si se está enfermo y trabajo remunerado), y el derecho a otras aspiraciones que todo ser humano y grupo desea poseer, como por ejemplo, derechos humanos, paz, justicia, opciones de vida digna, calidad de esa vida, posibilidad de crear, de innovar, de sentir placer, de tener acceso al arte y a la cultura.

Es precisamente la atención al derecho a esas otras aspiraciones ligadas al completo bienestar de las personas, las que justificarían el ingreso del juego en la agenda de las preocupaciones en materia de salud. 


\section{Philosophy International Journal}

[17], of the progressive construction of the use of one's own body. When adults educate the movement of children, they tend to quiet them, since their expectations of children are not related to body movement practices. Thus, adults fall into the contradiction of saying that children have to move, but they do little to effectively move them, since the adult's willingness to play with children is conditioned by the availability of free time and the desire to play.

In this framework, kindergarten, kindergarten, school, become places regularly frequented / inhabited by children where they get to meet others and have free time to try, to play, to learn. Coinciding with other children in wide and safe spaces, having time freed from homework, are conditions that make the garden and school scenarios that trigger motor play with others.

\section{Intensity and Innovation: Of the Game as a Concept}

Now, since ambiguity is a constitutive element of the game [18], an ambiguity that expresses a back and forth movement between antagonistic poles [19], those who promote game situations can favor order, respect for the rule, the socialization processes that become exclusive and, therefore, exclusive. This is the case of activities designed to achieve excellence, taking into account the potential of the virtuous, such as sport. Those who promote play situations can also favor freedom, creative and inclusive processes. This is the case of recreational and artistic activities designed so that everyone can participate, that is, to attend to diversity, and to avoid exclusion by recycling participation [20]. Both one position and the other have their virtues.

Stimulating order, respect for the rules (which in the game are agreed by the players), the recognition of traditions, of culturally constructed taste, of trying a more comfortable way of being and being in community, favors permanence, the preservation of the valuable, the recognition of the roots, the continuity in the protection of socialization.

Stimulating freedom, the possibility of mounting new situations, of trying alternative responses to old problems, of being and being in an unconventional way, of living and thinking about reality from a place other than everyday (perhaps from a character, or simply from the most genuine impulse to move, to do), it favors change, originality, the irruption of novelty through the launching of creativity.

The game contains that ambiguity. It cannot be one without the other. It is freedom and rule at the same time. It cannot be absolute freedom without a regulatory framework that enables it, and conversely, to be a game, it is not enough to move by following the rules, but there must be the possibility of changing them, of agreeing to them. The game is reality and appearance at the same time. It cannot be creation without the recognition of the socio-cultural reality as a starting point. And conversely, the usual, known, and foreseeable course of ordinary life must be interrupted to allow for unpredictability and uncertainty.

Paraphrasing Scharagrodsky who quotes Foucault when there are no practices of freedom, when a whole field of possibilities is closed, when reversibility mechanisms, modification strategies are obstructed, and relationships become fixed, we are faced with states of domination [21].

They were the voices of the players (children, adolescents, young people, but mainly older adults from PAMI) who participate in motor games days that we organize within the framework of the Knowledge and Play subject in the UNRC Physical Education teacher training, those that showed that gambling attracts people of any age because it sets people in motion and forces them to connect with themselves and with others, with what they do and with what they feel.

The inclusive potential that is recognized in the game then lies in the "intensity", "In that ability of hers (of the game) to lose his head" [1]. There where Pavía corrects himself saying "that when playing in a playful way beats the promise that something good is going to happen", there where the intense is connected with the intentional, where the emotions intertwine with the pretense and the decisions that are taken to collectively enjoy the moment. The playmate as an extension of one's own possibilities, as a power to one's own participation and not as an Other. The other brings with it novelty, innovation, unpredictability.

'Meaning', 'tension', 'intensity' are concepts that become central here, concepts that were said by Huizinga a century ago to refer to the essence of the game that which in his work explicitly communicates that he will not analyze, and that have gone unnoticed until now. Concepts that escape reason to be strongly linked to aesthetics, and that are tied to the possibility of detaching themselves from the logical scheme of everyday life.

The intensity of a genuine playful situation will make it an aesthetic experience. Precisely what defines an experience as aesthetics is its quality of being fully lived and experienced, enjoyed. This quality, which Dewey [22] calls tertiary, is perceived directly, without the intervention of reflection, because it permeates the situation to the point of constituting it.

Thinking about the intensity of the game in the evolutionary continuum paidia-ludus presented by Caillois [23], where the most complex pole, that is, ludus, 
is represented by the game itself, forces us to think about strategies to simplify the game in activities that allow to install the playful and in variants that make the game more complex without ceasing to be so (that is, without becoming sport, theater, for example).

Thinking didactic proposals from the intensity of the game requires professionals who are experts in the game, it forces us to study the game not only to the didactic resource but also to the concept in relation to the phenomenon [4]. It forces us to take the game as an object of study based on playful experiences in situ, where presence becomes irreplaceable, where humanity emerges, where putting oneself in the place of the other is an option [24-27].

\section{References}

1. Huizinga J (2000) Homo ludens. Alianza.

2. Batiuk V (2015) Educación Infantil: una prioridad política y social. Avances, agenda y estrategias. In: Tedesco JC (Ed.), La educación argentina hoy, Buenos Aires: Siglo XXI, pp: 235-279.

3. Vigotski L (2005) Psicología pedagógica. Ainque.

4. Centurión S (2017) El juego como propuesta académica. In: Rivero I, Ducart M (Eds.), El juego en la formación docente: Acerca del juego como recurso. Unirío.

5. Brougere G (1998) Jogo e educacao. Artes médicas.

6. Rabecq Maillard MM (1969) Historie des jeux éducatifs. Nathan.

7. Kishimoto T (2006) Jogo, brinquedo, brincadeira e a educacao. Cortez.

8. Kishimoto T (1998) Jogos infantis. 0 jogo, a crianca e a educacao. Voces.

9. Chateau J (1987) Psicología de los juegos infantiles. Kapelusz.

10. Pavía V (2006) Jugar de un modo lúdico. El juego desde la perspectiva del jugador. Noveduc.

11. Lydia P de Bosch (1992) Un jardín de infantes mejor. Siete propuestas. Paidós.

12. Mantilla L (2001) Juego y jugar, ¿un camino lineal y sin retorno? Estudios sobre las culturas contemporáneas
4(12): 101-123.

13. Lavega Burgués P (2000) Juegos y deportes populares y tradicionales. Inde.

14. Rivero I (2011) El juego en las planificaciones de Educación Física. intencionalidad educativa y prácticas docentes. Novedades educativas.

15. Unicef (2013) Observaciones Generales del Comité de los Derechos del Niño. DIF Nacional.

16. Rivero I (2018) Prácticas corporales en jardines maternales de gestión pública de la ciudad de Córdoba. Revista IRICE 34: 161-193.

17. Gómez R (1999) Aportes para una didáctica de la disponibilidad corporal en cuanto el cuerpo es protagonista. Educación Física- Novedades Educativas, pp: 13-20.

18. Sutton Smith B (1977) The ambiguity of play. Harvard University Press.

19. Gadamer H (2005) La actualidad de lo bello. Paidós.

20. Ledesma A, Fraenkel A, Mariscotti E (2014) Tránsitos de lo corporal. Novedades educativas, pp: 64-68.

21. Scharagrodsky P (2013) Discursos pedagógicos, procesos de escolarización y educación de los cuerpos. In: Varea V, Galak E (Eds.), Cuerpo y Educación Física. Perspectivas latinoamericanas para pensar la educación de los cuerpos, Biblos, pp: 15-44.

22. Dewey J (2008) El arte como experiencia. Paidós.

23. Caillois R (1986) El juego y los hombres. La máscara y el vértigo. Fondo de Cultura Económica.

24. Ortíz G (2011) Tiempos indigentes. Sobre la religión, la educación y la pregunta por el sentido. EDUCC.

25. Pavía V (2009) Las formas del juego y el modo de jugar que la escuela reproduce. Revista de Psicologia, Ciències de l'Educació i de l'Esport 25: 161-178.

26. Piaget J (1997) La formación del símbolo en el niño. Imitación, juego y sueño. Imagen y representación. Fondo de Cultura Económica.

27. Martinis P, Redondo P (2006) Igualdad y educación : Escrituras entre dos orillas. Del Estante. 